\title{
Nano-MOOC: Public Finance Techno- Pedagogy-Learning Resource at Universidad Técnica del Norte
}

\author{
Elizabeth Ibadango-Galeano ${ }^{1, *}$, Alexander Guevara-Vega ${ }^{2,3}$, Erick Herrera Granda ${ }^{3}$ \\ ${ }^{1}$ Instituto de Posgrado, Universidad Técnica del Norte, Ibarra, Ecuador \\ ${ }^{2}$ Facultad de Ingeniería en Ciencias Aplicadas FICA - UTN, Ibarra, Ecuador \\ ${ }^{3}$ Grupo de Investigación de Ciencias en Red eCIER- UTN, Ibarra, Ecuador
}

Received March 20, 2020; Revised May 11, 2020; Accepted January 25, 2021

\begin{abstract}
Cite This Paper in the following Citation Styles
(a): [1] Elizabeth Ibadango-Galeano, Alexander Guevara-Vega, Erick Herrera Granda, "Nano-MOOC: Public Finance Techno-Pedagogy-Learning Resource at Universidad Técnica del Norte," Universal Journal of Educational Research, Vol. 9, No. 4, pp. 748 - 756, 2021. DOI: 10.13189/ujer.2021.090406.
\end{abstract}

(b): Elizabeth Ibadango-Galeano, Alexander Guevara-Vega, Erick Herrera Granda (2021). Nano-MOOC: Public Finance Techno-Pedagogy-Learning Resource at Universidad Técnica del Norte. Universal Journal of Educational Research, 9(4), 748 - 756. DOI: 10.13189/ujer.2021.090406.

Copyright $\bigcirc 2021$ by authors, all rights reserved. Authors agree that this article remains permanently open access under the terms of the Creative Commons Attribution License 4.0 International License

\begin{abstract}
This research aims to identify the technological tools used by teachers in training processes to design a techno-pedagogical resource called Nano-MOOC to improve teaching and strengthen the academic performance in the Public Finance subject of the Technical University of the North (Universidad Técnica del Norte - UTN) located in the city of Ibarra-Ecuador. Research is an exploratory study, through a mixed, bibliographic, and documentary approach of a descriptive cross-sectional type, the relevance, and the need and importance of technology and techno-pedagogical resources in the teaching-learning process were demonstrated; statistical techniques were used as a methodology in RStudio; the additivity assumption was applied with the observation of the bivariate correlation matrix for a normal distribution of the data. Two variables were established: 1) The need to implement technology by teachers; 2) The importance of technology as a techno-pedagogical tool for improvement for students. The factor structure was excellent. An Anova of variable 1 was applied, which gave a $\mathrm{p}=$ value of 0.036 which considers students between 17 to 24 years who consider the implementation of a Nano-MOOC more necessary. The results show the validity and reliability of the construct that was demonstrated by the Confirmatory Factor Analysis that a Nano-MOOC as a techno-pedagogical resource is
\end{abstract}

relevant for micro-learning. It is concluded that it is the digital natives who consider this implementation most necessary; teachers do not apply technological tools due to ignorance. A Nano-MOOC improves, feeds back the teaching-learning process, and is useful and sustainable to achieve successful professionals in academic and work performance.

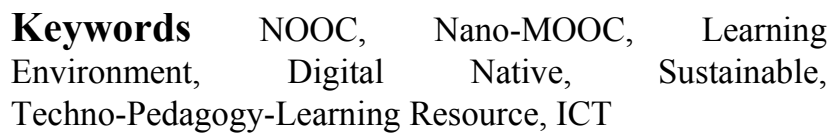

\section{Introduction}

Knowledge society tackles education actors towards co-creation approaches that have a positive impact on education so that we are capable of coping with changing contexts [9]; this characteristic corresponds to a rapid increase in knowledge production, innovation and the enhancing systematic use of technology [2]; in the midst of the XXI century, a technological paradigm evolves to build and acquire knowledge and better learning opportunities [16]; education, knowledge and research transform a technological society's conduct [38]. 
Technological evolution delivers educational innovation enabling apps, educational programs and software, massive online courses, online platforms virtual learning environments as well as virtual learning objects to enhance education and revolutionize traditional higher education settings. In this way, modern societies may offer online quality education available to everyone.

In this scope, it develops abilities and micro-knowledge through effective activities in educational environments [18]; technological advances have made simple learning implying the redesign of traditional courses into online courses because its original model was not efficient [5]. Therefore, it is vital to innovate conventional online courses so that they become interactive and productive tools accessible to native and digital immigrants enriching learning solidly.

Several authors state that learning technology improves the quality of instruction having a positive impact on academic performance, in addition, having expert faculty is key to this learning process [12],[33]. Information and Communication Technologies (ICT) evolve as sustainable agents in an innovative ecosystem together with web 2.0 which support e-learning, b-learning and m-learning modes in learning environments where digital and immigrant natives generate knowledge [3],[13].

E-learning contributes to university contexts, incorporating Web 2.0, 3.0 benefiting educational development evidencing high scores, turning into microecological knowledge [20],[39],[6]; blending innovating resources with technology and science solves problems and supports knowledge for future challenges [7]; promoting online education contributes to environmental protection since assignments are due on line. Therefore, the excessive use of paper is almost certainly eliminated.

Authors confirm that environmental educations support sustainable development objective-ODS-since it protects the natural environment, creates awareness and the innovation of revolutionary technological resources and also the creation of new learning environments offering new learning opportunities so that formal and informal education is supported [31],[10],[23],[30]; microlearning is taught by technological resources including key-topic short video-clips having the potential to enhance professional development and the innovation of traditional methodologies to improve academic performance [8],[15],[11].

At this pace, MOOC--Massive Open Online Course - which tremendously helps traditional learning through efficient didactic methodology [34]; MOOC contains forums, chats, calendars and didactic resources to surf the world wide web [27]; vital for higher education although its quality and pedagogic design is somehow worrying because there is still systematization and error factors modification as well as content, timing and log out functions correction [28],[25],[1],[14].

Although MOOCs play an innovative role in virtual education offering lengthy courses containing immense amount of information, these courses drastically affect students learning and time management. Therefore, students experience feelings of uncertainty and anxiety resulting in course "drop-outs" and that's when Nano-MOOC's come in. These are short 10-15 min online courses taught in virtual environments providing objective content that support learning and create highly effective educator-student communication promoting educational success.

Although Nano-MOOC-Nano Open Course Online - is uncommon, they provide micro-learning digital competencies that try to look into depth academic topics, because of time and space they are omitted [40],[32], [24]; the creation of pedagogic tools based on connectivity that acknowledges tectonic movements in society is imperative to obtain significative learning [37]. INTEF [17] reveals that MOOC takes in NOOC (Nano-MOOC) because they are valid and significative techno-pedagogical resources helpful in day-to-day education tasks. LOES Art. 08 supports technological innovations that contribute to virtual learning models at UTN, seeking innovative sensible solutions to academic issues [29]; analyzed in this study.

In this study, the implementation of technology and techno-pedagogical tools such as Nano-MOOCs helps to obtain content feedback by educators who cannot easily obtain it because of the lengthy and strict lesson plans and syllabus to be met. For instance, commonly used methods like dictation using paper and pencil in tests can be avoided by introducing suitable technological tools intended to familiarize native and immigrant digital students with such resources.

As a consequence of educators' minimum management of digital competences, they are highly likely to misuse technology, in addition to not being familiarized with an instructional design helpful in the planning of online courses so that these courses are implemented in the classroom. As a result, students certainly experience demotivation that may lead to low academic performance, which almost certainly may affect work performance, particularly in the area of Public Finance in case that students ever get to have a public position.

According to what has been mentioned, the objective of this research is to identify the technological tools used by teachers in the training processes of the Public Finance subject in the Accounting and Auditing career at the FACAE faculty, of the Universidad Técnica del Norte, and carry out an analysis of the educational situation of the students to highlight the following questions: 1) Is there a need to implement technology and techno-pedagogical tools to improve the teaching-learning process of the Public Finance subject? 2) At what age will the implementation of a Nano-MOOC be more necessary? 3) Is it pertinent to carry out a Nano-MOOC as a techno-pedagogical resource in the Public Finance subject? 


\section{Methodology}

This investigation is an exploratory study using a quantitative-descriptive, bibliographic, documentary and field approach. Teachers and students were willing to collaborate in the study. This research work describes objective related components, frequency, average and parameters with confidence intervals [26]; For its effect the following phases were defined: state of the art; situational diagnosis of the sample; analysis and interpretation.

\section{Phase 1 - State of the art}

The data collection was carried out since May 2019, with bibliographic review in repositories and database of the UTN virtual library such as Springer, Scopus, SCimago, ProQuest, as well as in Google Scholar, Microsoft Academic. Fifty bibliographic references were obtained according to keywords such as educational technology, NOOC, digital natives and immigrants, technological tools, techno-pedagogical resources and ICT related to the problem of research and the search for solutions.

\section{Phase 2 - Situational diagnosis}

To unveil the actual situation in regards to educators' use of technological tools when teaching the subject of Public Finance, an assessment matrix was developed including objectives, variables and indicators, techniques and population estimate as well with the purpose of establishing three basic components: learning process, techno-pedagogical resources and academic performance. Such components help obtain a solid data gathering process in the study.

The survey technique was used with its instrument, the questionnaire, which was validated by four ICT experts. After several reviews, corrections, substitution of questions and the placement of sections, this instrument was specified with 17 multiple-choice questions on a Likert assessment scale presented in order and clarity. The instrument was carried out through Google forms and was applied to 73 students of Public Finance. Kalnow [19] point out that Google forms are a free online application to get immediate results of research data. In addition, two teachers who taught the Public Finance course were interviewed with 15 questions to collect information and learn about the current situation in which students are developing in terms of the use of techno-pedagogical resources in the classroom. Direct observation was essential in this study to verify how the teacher gives the classes.

The research was carried out with 73 students and 2 teachers in an empirical observation space that was UTN, FACAE, in the Accounting and Auditing degree program, located in the city of Ibarra-Ecuador, El Sagrario parish. This allowed collecting important information and constituting the total sample for the study. See Table 1.
Table 1. Sampling by gender.

\begin{tabular}{ccc}
\hline Gender & Number & Percentage \\
\hline Males & 17 & 23,3 \\
Females & 53 & 72,6 \\
LGBT & 3 & 4,10 \\
Total & $\mathbf{7 3}$ & $\mathbf{1 0 0}$ \\
\hline
\end{tabular}

Source: Public Finance Students at UTN

Researcher: E. Janeth Ibadango.G.

\section{Phase 3 - Results analysis and interpretation}

At this stage, the statistical program RStudio was used to analyze the behavior of the data using the statistical technique for the assumption of additivity with the observation of a bivariate correlation matrix of combination of questions, where none reaches 0.95 . The data come from a normal, linear distribution, and have homogeneity and homoscedasticity by means of the Scatter Plot analysis; the values are adjusted and the residuals are standardized, being observed as a Barlet cloud.

Then, to answer the question: Is there a need to implement technology and techno-pedagogical tools to improve the teaching-learning process Public Finance subject? Two variables were established through a confirmatory factor analysis called; 1) Need to implement technology by teachers; 2) Importance of technology as a techno-pedagogical tool for improvement for students. Consequently, the structure was valid and reliable for this study, constituting according to the RMSEA indexes of 0.000 , SRMR of 0.022 whose values are minimal to 0.05 . Thus, the construct is excellent because implementation improves the teaching-learning process.

Subsequently, an ANOVA of variable 1 was applied with the three groups of students from 17 to 20,21 to 24 and 33 to 48 years of age; the p-value was 0.036 less than 0.05 . Notably, there is a significant difference between the three age groups. Finally, to corroborate the above, a Pairwise $\mathrm{T}$ test was applied to answer the question: At what age will the implementation of a Nano-MOOC be most necessary? Consequently, it is the digital natives between 17 and 24 years of age who consider it most necessary. Indeed, this implementation evidences the relevance of designing a Nano-MOOC as a techno-pedagogical resource in the Public Finance subject. This result answers the question: Is it pertinent to carry out a Nano-MOOC as a techno-pedagogical resource in the Public Finance subject? Afterwards, for its development, a specialized diagnosis must be carried out and the specific topic identified, where the student presents learning difficulties and the specific Nano-MOOC must be designed, which will be carried out in other investigations.

The ANOVA statistical test was applied to compare the variable need to implement technology (variable) by teachers, within the strata that constitute the ages of the students between 17 to 20,21 to 24 and 33 to 48 years old 
who are studying Public Finance in the Accounting and Auditing program, FACAE of the UTN.

\section{Results}

Results were obtained in an Excel sheet for statistical testing using programming language RStudio 3.6.3. Initially, the parametric statistical technique for the additivity scenario was examined through a bivariate correlation matrix observation, specifically in a combination of questions. Results obtained for the correlation matrix showed that none of the values reaches over 0.95 and thus additivity is accepted. See Fig. 1.

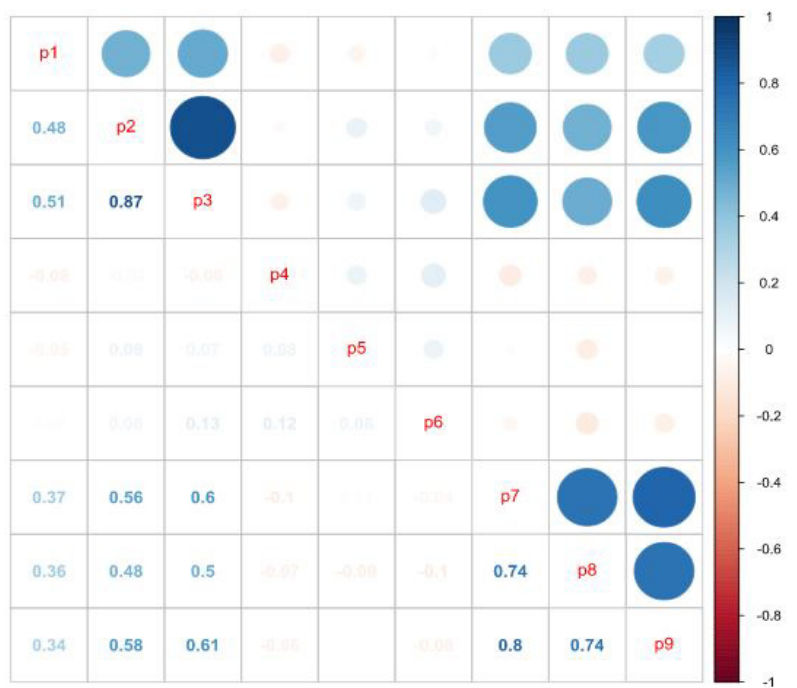

Figure 1. 73 Surveys' Matrix Correlation Histogram Dispersion

After that, normal assumptions of normality, linearity, homogeneity and homoscedasticity were verified. Moreover, a random value false regression "Chi Square Test" as a predicted deviation by all relevant values from a set of standardized for quantiles data was applied.

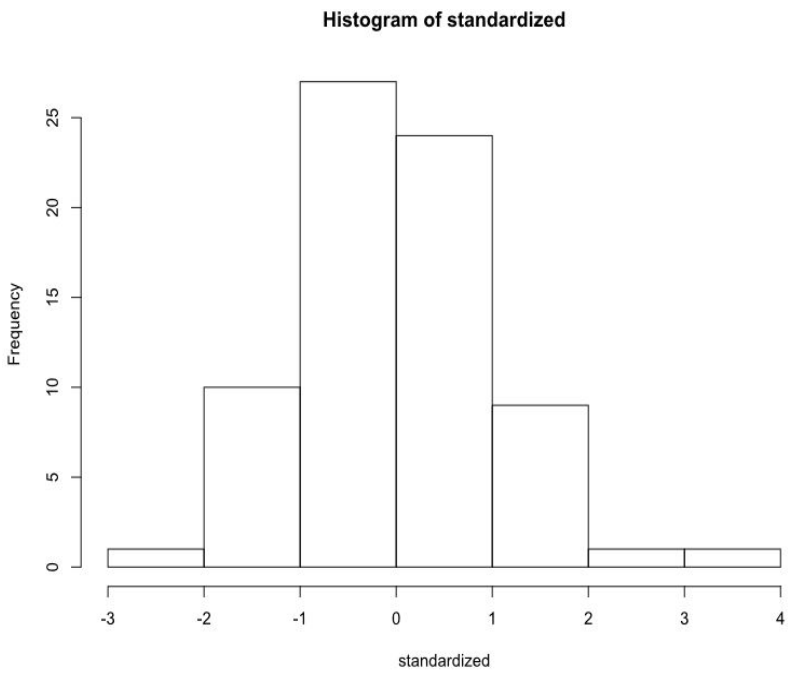

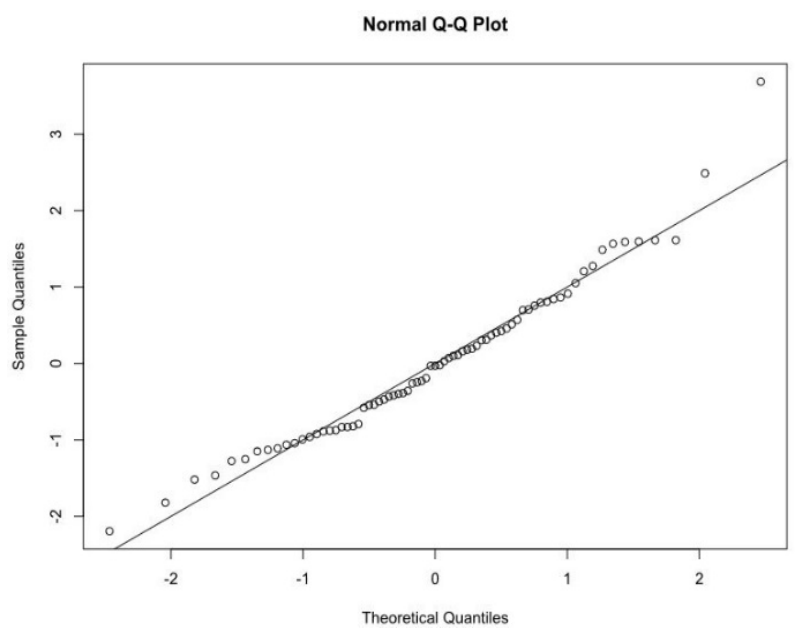

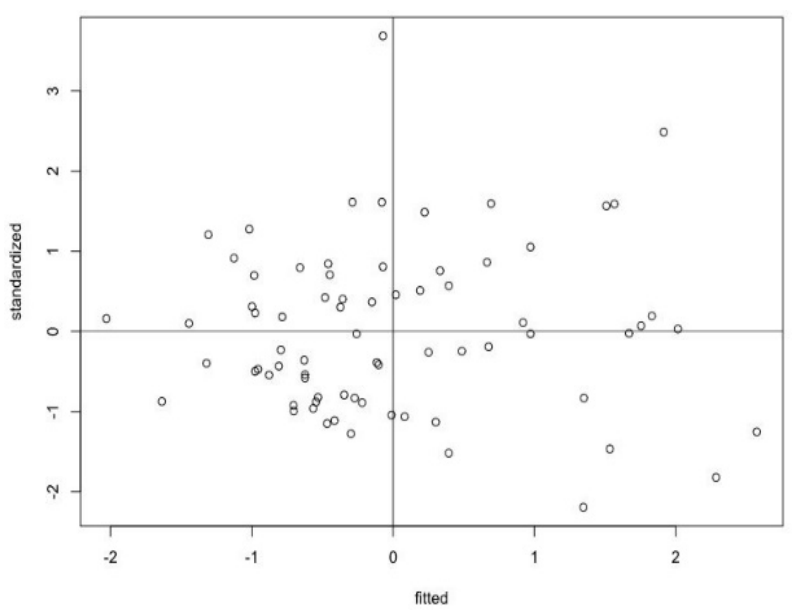

Figure 2. Histogram, QQ Plot, Scatter Plot

Assumption normality is obtained by observing histogram regression quantiles near normal distribution. Frequency distributions show a central normal tendency from 2 to 2. Linearity was obtained from theoretical and predicted deviations. It is verified then, that quantiles appear along a straight line in a 2 to 2 intervals. Finally, homogeneity and homoscedasticity are obtained through a Scatter Plot analysis. Values are adjusted, residues are standardized, and quantiles distributed evenly-equal number - in the 4 quadrants which are not apart, nor do they take a set form. Similarly, quantile homoscedasticity path is interspersed in the quadrants in which there are no shapes or patterns. It is just seen as a Barlet Cloud. See Fig. 2.

In this scope, a confirmatory analysis is done and question 5 is eliminated resulting in 2 set variables.

The need to implement technology by faculty members

Q1-Do you think that faculty members are willing to help reinforce learning when you need to?

Q2-Do you think that faculty members should look for virtual environments outside the classroom so as to promote learning to become efficient students?

Q3-Do you think face-to-face classes are enough to get 
thorough knowledge of the Public Finance academic subject?

Importance of technology as techno-pedagogic tool to enhance student learning

Q7 Would you like to increase academic performance levels related to Public Finance through a techno-pedagogic resource?

Q8 Do you think that the use of social networks is necessary to keep up-to-date in regards of homework and timetables so that organization of study time becomes more efficient?

Q9 Do you think the use of Nano-MOOC is essential as a techno-pedagogic resource to enhance Public Finance academic performance?

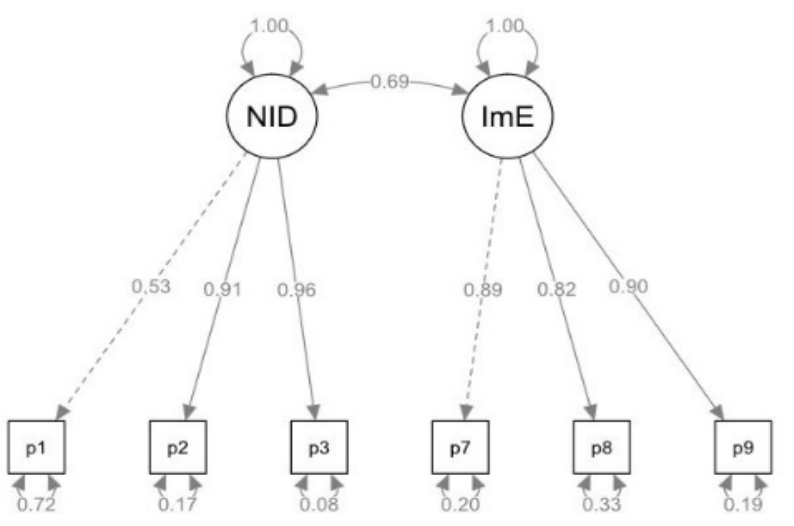

Figure 3. Confirmatory Factor Analysis Chart

Confirmatory factor analysis helps the validation of factorial structure showing adequate research rates [35]. Therefore, saturation for each question is over 0.5 and consequently, the final structure is valid and reliable. See Fig. 3.
Eventually, saturation is over 0.5 , which Trucker index and Lewis are 1.032 and 1.032 respectively. NNFI (Non Normed Fit Index) falls into the $>0.95$ index. CFI value of 1.000 falls into the "excellent" category. On the other hand, RMSEA index (Root Mean Square Error of Approximation) and SRMR (Standardized Root Mean Residual) obtained values from 0.000 and 0.022 demonstrate the construct validity due to a 0.05 minimum value. See Fig. 4.

The need of the implementation of Nano-MOOC density ponderation according to age

Table 2. Anova Results

\begin{tabular}{ccccc}
\hline Effect & DFn & DFd & F & p p $<.05$ \\
\hline Group & 2 & 15 & $4.17476-0.03619093$ & 0.3575885 \\
Total & 2 & 15 & $4.17476-0.03619093$ & 0.3575885 \\
\hline
\end{tabular}

Source: Public Finance Students UTN

Researcher: E. Janeth Ibadango.G.

ANOVA statistical tests applied to measure the variable in regards to the need for technology implementation - variable - from faculty members and to student groups between 17 to 20,21 to 24 and 33 to 48 years of age who are studying Public Finance in the Accounting and Auditing program, FACAE of the UTN. Saravia [36] mentions that ANOVA, created by Ronald Fisher in $(1980$ - 1962) verifies the differences between 3 or more groups and determines whether there are differences among them showing a certain quality. Through this analysis, a p-value is $0.036(\mathrm{p}<0.05)$, See Table 2. It is notably verified a significative difference between the three age-groups thus the application of techno-pedagogic resources is critical for digital and native and immigrants Public Finance students.

\begin{tabular}{|c|c|c|c|c|}
\hline npar & fmin & chisq & $d f$ & pvalue \\
\hline 13.000 & 0.020 & 2.971 & 8.000 & 0.936 \\
\hline baseline.chisq & baseline.df & baseline.pvalue & cfi & tli \\
\hline 310.917 & 15.000 & 0.000 & 1.000 & 1.032 \\
\hline nnfi & $\mathrm{rfj}$ & nfi & pnfi & ifi \\
\hline 1.032 & 0.982 & 0.990 & 0.528 & 1.017 \\
\hline rni & $\log 7$ & unrestricted. $\log 1$ & aic & b \\
\hline 1.017 & -831.677 & -830.192 & 1689.354 & 1719.130 \\
\hline ntotal & bic2 & rmsea & rmsea.ci. lower & rmsea.ci.upper \\
\hline 73.000 & 1678.167 & 0.000 & 0.000 & 0.034 \\
\hline rmsea. pvalue & $\mathrm{rmr}$ & rmr_nomean & srmr & srmr_bentle \\
\hline 0.962 & 0.105 & 0.105 & 0.022 & 0.022 \\
\hline srmr_bentler_nomean & $\mathrm{crmr}$ & crmr_nomean & srmr_mplus & srmr_mplus_nomea \\
\hline 0.022 & 0.026 & 0.026 & 0.022 & 0.022 \\
\hline cn_05 & cn_01 & gfi & agfi & $\mathrm{pg}$ \\
\hline 382.030 & 494.637 & 0.986 & 0.964 & 0.37 \\
\hline$m f i$ & ecvi & & & \\
\hline 1.035 & 0.397 & & & \\
\hline
\end{tabular}

Figure 4. Adjustment in positive index 


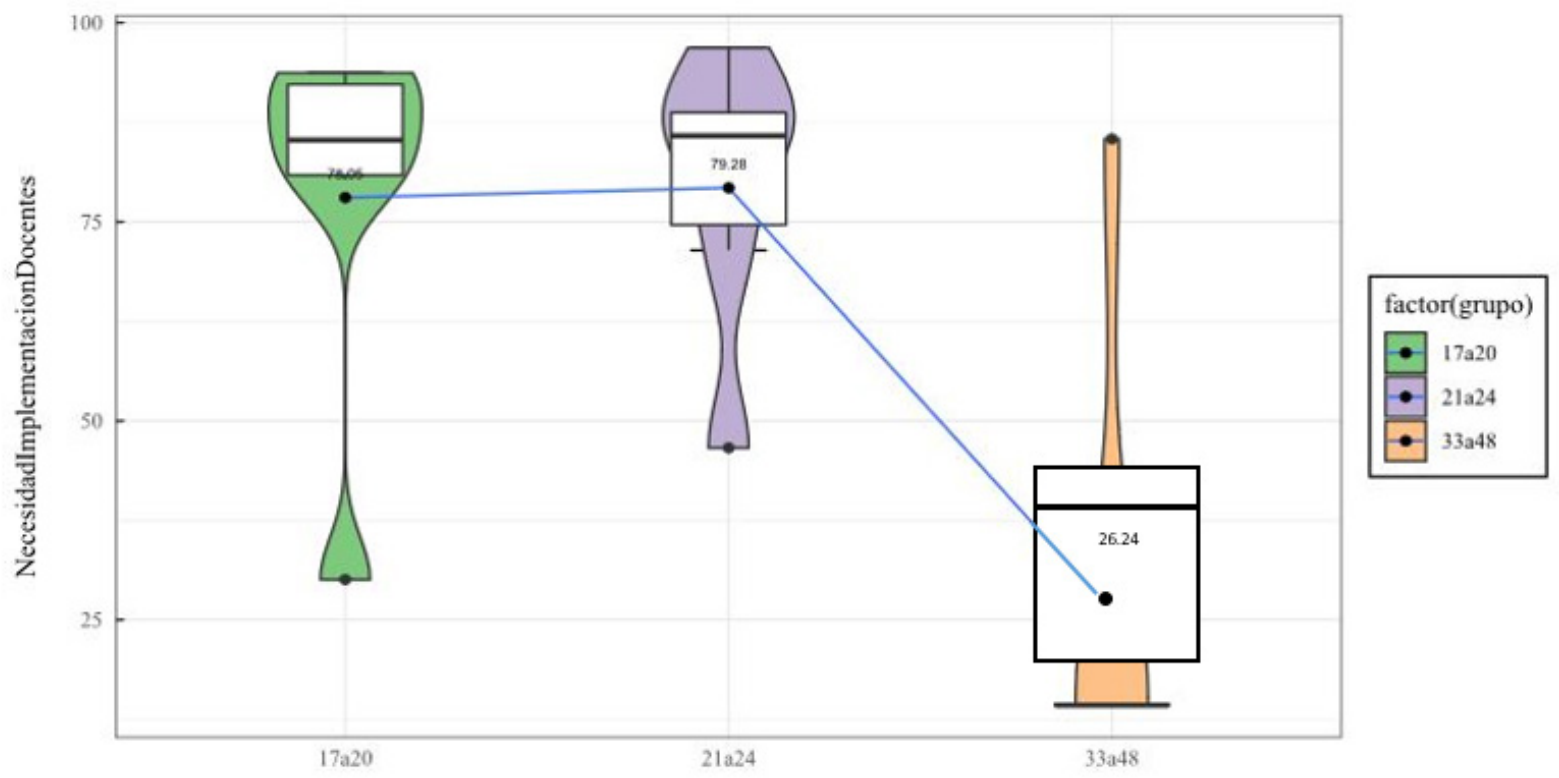

Figure 5. Boxed Chart

Table 3. Pairwise comparisons using $t$ tests with pooled SD

\begin{tabular}{cc}
\hline Age & P Value method: bonferroni \\
\hline 17 a 20 & 1.0000 \\
21 a 24 & 0.0051 \\
33 a 48 & 0.0062 \\
\hline
\end{tabular}

Source: UTN Public Finance Students

Researcher: E. Janeth Ibadango.G.

Finally, Pairwise $T$ statistical test provides a $P$ value in multiples comparisons using $P$ values in a triangular matrix among the groups [4]. As observed in Table 3, there is a significative difference in regards to the need for implementation of a Nano-MOOC as a techno-pedagogical resource in the Public Finance, among the group of 17 to 20 -year-old's. As far as the 33 to 48-year-old group showing a $0.0062 \mathrm{p}$-value, whereas as the 17 to 20 -year-old group thinks the need for this implementation is greater. What is more, there is a significative difference between 21 to 24 year-old students in contrast to the 33 to 48 -year-old group, showing a $0.0051 \mathrm{p}$-value where the 21 to 24-year-old group thinks the implementation is highly needed. See Fig. 5.

\section{Results and Discussion}

The results of this research stand out in that the application of a techno-pedagogical resource resulting from ICT provides quality in the learning process and it is successful to use the so-called Nano-MOOCs because they allow improving and supporting university training. Moreover, the research addresses issues that the teacher leaves out due to the lack of time and space; they are sometimes even taken into account in the planning but teachers cannot teach them. Therefore, students are left with gaps that they could get to learn, and those information gaps could even make a difference in their professional life, but due to ignorance and traditional methods teachers do not implement them.

The results of Basantes [2] were successful because they took advantage of ICT as an innovation and since they strengthened the teaching-learning process. This agrees with this study because a Nano-MOOC is an educational innovation of micro-learning whose use allows solving academic difficulties and supports improving the academic performance of students. In a study from the Global South, its application improved learning with significant effects [22].

The implementation of Nano-MOOCs certainly reinforces ODS by proposing the creation of a Public Finance techno-pedagogical resource as well as e-learning with the aim to protect the natural environment. In support to ODS, a proposal for the creation of a Public Finance techno-pedagogic resource and online learning apt to protect the natural environment is proposed [31],[10],[23].

Results based on micro-learning practices were key to the traditional classroom innovation. In this context, Nano-MOOC innovates traditional processes for enhanced academic performance [15],[11]; findings regarding the importance of learning environment designs from university students perspective validated the concept for better learning competencies applied to formal and informal educational processes [30].

There are a number of courses in virtual learning environments, but many times they lack an optimal and well defined instructional design (ID) due to the teachers' ignorance. The content is extensive it takes them months, the student gets tired and drops out of the course without achieving solid knowledge. Therefore, the need to implement technology and techno-pedagogical tools to improve the learning process of Public Finance is valid and 
reliable.

To confirm this research studies addressed in the pedagogic quality MOOCs and the design showed that they do not tackle lateral issues, nor focus on the acknowledgment of micro-learning practices since these tools only focus on course finalization not on the strengthening of acquired knowledge, and certainly, they lack of learning feedback and lengthy content has caused a high level of MOOC course drop outs [28],[21].

Therefore, a proposal for the creation of Nano-MOOC as a techno-pedagogic resource that enhances micro-learning practices allowing a 15-minute Nano-MOOC 15 instead of a months-long MOOC would certainly become an attractive academic offer that may well benefit students learning. Unfortunately, this offer needs further scientific research.

Consequently, with Fermín [14] pilot result for the adoption of a Nano-MOOC at Chile University, INACAP provided a flexible model to tackle research-action topics and competences which outcome was attractive and motivating because it decreases MOOC dropout rates. Therefore, research done at Universidad Técnica del Norte-FACAE, the Accounting and Auditing department in Ibarra-Ecuador, provides results that evidence the need for designing a Nano-MOOC to be implemented to the subject of Public Finance so that the learning process is enhanced by strengthening knowledge firmly and in turn, improve academic performance so future professionals do their jobs efficiently.

Results from Pérez [32] confirm this study since the implementation of nine Nano-MOOC courses to enhance students training, resulted in a low-information-concrete and defined learning strategy providing learning feedback as this study suggests by looking into previously ignored topics vital for future Public Finance professionals' higher education.

INTEF [17] confirms that online studying enhances concrete profound learning related to efficient professional development, therefore this study is considered innovative for the training of successful professionals.

Creating a Nano-MOOC requires the establishment of an exceptional instructional design formed in a virtual environment where there is no educator present. Additionally, the content should be specific within a time limit so as to significatively contribute to digital natives 17 to 24 year-olds micro-learning processes aiming to lower course drop-out statistics by Nano-MOOCs utilization.

To sum up, Public Finance students and faculty were motivated by these new ways of learning and innovating learning processed. Furthermore, this research confirms the need and importance to implement technological learning tools so that university students benefit from feedback and self-online learning.

\section{Conclusions}

The following conclusions were obtained from the results: 1) Through the carried-out study, it is concluded that students between 17 to 24 years of age consider the implementation of a Nano-MOOC more necessary, because they positively perceive innovating with educational technology as they are digital natives; therefore, they should take full advantage of academic offerings online that provide ICT in the educational field. 2) With the results obtained and direct observation in class, it was shown that teachers practically do not apply technological tools and the level of use of ICT is very low; thus, it is valid and pertinent to carry out a Nano-MOOC as a techno-pedagogical resource in the Public Finance subject to innovate university education based on the need and importance that these resources focus. This can contribute to academic performance and to strengthening the construction of significant knowledge for the students' future performance as successful professionals. 3) The relevance of creating a Nano-MOOC in the Public Finance subject was confirmed and it is concluded that it can be used to improve and provide feedback to the teaching-learning process because the face-to-face hours are not enough. 4) The Nano-MOOC is a sustainable educational techno-pedagogical resource that supports the SDGs in protecting the natural environment, does not use paper or polluting ink, has online activities that promote micro-learning and contributes to the virtual educational model of the UTN.

\section{REFERENCES}

[1] Albelbisi, N. A. The role of quality factors in supporting self-regulated learning (SRL) skills in MOOC environment. Education and Information Technologies, 24(2), 1681-1698. Retrieved from: https://doi.org/10.1007/s10639-018-098552 (2019).

[2] Basantes, A. V., Naranjo, M. E., Gallegos, M. C., y Benítez, N. M. Los dispositivos móviles en el proceso de aprendizaje de la facultad de educación ciencia y tecnología de la universidad técnica del norte de ecuador. Formacion Universitaria, 10(2), 79-88. Retrieved from: https://doi.org/10.4067/S0718-50062017000200009 (2017).

[3] Belousov, D. R., y Penukhina, E. A. On the Construction of a Qualitative Model of the Russian ICT Ecosystem. Studies on Russian Economic Development, 29(3), 295-302. Retrieved from: https://doi.org/10.1134/S1075700718030024 (2018).

[4] Boone, S. Multiple Paiwise Comparisons, R Pubs por Rstudio. Retrieved from: https://rpubs.com/stephanieboone/ 300924 (2017).

[5] Borchardt, J., \& Bozer, A. H. Psychology course redesign: an interactive approach to learning in a micro-flipped classroom. Smart Learning Environments, 4(1), 10. Retrieved from: https://doi.org/10.1186/s40561-017-0049-3 (2017).

[6] Borge, M., \& Mercier, E. Towards a micro-ecological approach to CSCL. International Journal of 
Computer-Supported Collaborative Learning, 14(2), 219-235. Retrieved from: https://doi.org/10.1007/s11412-0 19-09301-6 (2019).

[7] Brand, B. R. Integrating science and engineering practices: outcomes from a collaborative professional development. International Journal of STEM Education, 7(1), 13. Retrieved from: https://doi.org/10.1186/s40594-020-00210$\mathrm{x}(2020)$.

[8] Cheng, J. Learning to attend to precision: the impact of micro-teaching guided by expert secondary mathematics teachers on pre-service teachers' teaching practice. ZDM, 49(2), 279-289. Retrieved from: https://doi.org/10.1007/s1 1858-017-0839-7 (2017).

[9] Di Nauta, P., Merola, B., Caputo, F., y Evangelista, F. Reflections on the Role of University to Face the Challenges of Knowledge Society for the Local Economic Development. Journal of the Knowledge Economy, 9(1), 180-198. Retrieved from: https://doi.org/10.1007/s13132-015-0333-9 (2018).

[10] Edsand, H.-E., \&Broich, T. The Impact of Environmental Education on Environmental and Renewable Energy Technology Awareness: Empirical Evidence from Colombia. International Journal of Science and Mathematics Education, 18(4), 611-634. Retrieved from: https://doi.org/10.1007/s1 0763-019-09988-x (2020).

[11] Essmiller, K., Thompson, P., \& Alvarado-Albertorio, F. (2020). Performance Improvement Technology for Building a Sustainable OER Initiative in an Academic Library. TechTrends, 64(2), 265-274. Retrieved from: https://doi.or g/10.1007/s11528-019-00467-2 (2020).

[12] Fahrman, B., Norström, P., Gumaelius, L., \&Skogh, I.-B. Experienced technology teachers' teaching practices. International Journal of Technology and Design Education, 30(1), 163-186. Retrieved from: https://doi.org/10.1007/s1 0798-019-09494-9 (2020).

[13] Falco, M. Reconsiderando las prácticaseducativas: TICs en el proceso de enseñanza-aprendizaje / Rethinking Educational Practices: ICTS in the teaching-learning process. TendenciasPedagógicas, 29(2017), 59-76. Retrieved from: https://doi.org/10.15366/tp2017.29.002 (2017).

[14] Fermín, M., \& Ledesma, D. MOOC "Matemática para el futuro: Accesibilidad e inclusión para estudiantes de educación media.” In Congreso ITIE (pp. 1-6). (2018).

[15] Garber, A. M. Flipping Out! Utilizing an Online Micro-lecture for Asynchronous Learning Within the Acting Internship. Medical Science Educator. Retrieved from: https://doi.org/10.1007/s40670-019-00887-y (2019).

[16] IbadangoGaleano E., Enríquez E.P., Yacelga U.Q., Rosas W.M., Taquez M.Q. NEOBOOK: Hypermedial Language Integrating Knowledge in Computer Education. In: Basantes-Andrade A., Naranjo-Toro M., Zambrano Vizuete M., Botto-Tobar M. (eds) Technology, Sustainability and Educational Innovation (TSIE). TSIE 2019. Advances in Intelligent Systems and Computing, vol 1110. Springer, Cham Retrieved from: https://doi.org/10.1007/978-3-030-3 7221-7_2(2020).

[17] INTEF. Aprendizaje en línea para una transformación digital de la educación. En: NOOC. Retrieved from: https://aprende.intef.es/, acceso 18 de Febrero (2020).
[18] Kenkre, A. B., \& Murthy, S. MIC-O-MAP: a technology-enhanced learning environment for developing micro-macro thinking skills. Research and Practice in Technology Enhanced Learning, 12(1), 23. Retrieved from: https://doi.org/10.1186/s41039-017-0063-7 (2017).

[19] Kalnow, A., Lloyd, C., Casey, J., \& Little, A. Google Forms-A Novel Solution to Blended Learning. Journal of Education and Teaching in Emergency Medicine, 4(2), 1-9. (2019).

[20] Lara, J. A., Aljawarneh, S., \& Pamplona, S. Special issue on the current trends in E-learning Assessment. Journal of Computing in Higher Education, 32(1), 1-8. Retrieved from: https://doi.org/10.1007/s12528-019-09235-w (2020).

[21] Leach, M., \&Hadi, S. M. Supporting, categorising and visualising diverse learner behaviour on MOOCs with modular design and micro-learning. Journal of Computing in Higher Education, 29(1), 147-159. Retrieved from: https://doi.org/10.1007/s12528-016-9129-6 (2017).

[22] Lim, C. P., Ra, S., Chin, B., \& Wang, T. Information and communication technologies (ICT) for access to quality education in the global south: A case study of Sri Lanka. Education and Information Technologies. Retrieved from: https://doi.org/10.1007/s10639-019-10069-3 (2019).

[23] Lizcano, D., Lara, J. A., White, B., \&Aljawarneh, S. Blockchain-based approach to create a model of trust in open and ubiquitous higher education. Journal of Computing in Higher Education, 32(1), 109-134. Retrieved from: https://doi.org/10.1007/s12528-019-09209-y (2020).

[24] López-Meneses, E., Cobos-Sanchiz, D., Martín-Padilla, A. H., Molina-García, L., \& Jaén-Martínez, A. Libro 3. Experiencias pedagógicas e innovación educativa: aportaciones desde la praxis docente e investigadora. (2018).

[25] Maya, I., Holgado, D., González, E., Castaño, J., y Punie, Y. Typology of motivation and learning intentions of users in MOOCs: the MOOCKNOWLEDGE study. Educational Technology Research and Development, (0123456789). Retrieved from: https://doi.org/10.1007/s11423-019-096823 (2019).

[26] Monjarás-Ávila, A. J. ., Bazán-Suárez, A. K. ., Pacheco-Martínez, Z. K. ., Rivera-Gonzaga, J. A., Zamarripa-Calderón, J. E. ., y Cuevas-Suárez, C. E. . Diseños de Investigación. ESaludyeducación, 15(15), 119-122. (2019).

[27] Monllaó, D., Huynh, D. Q., Reynolds, M., Dougiamas, M., \& Wiese, D. A supervised learning framework: using assessment to identify students at risk of dropping out of a MOOC. Journal of Computing in Higher Education, (0123456789). Retrieved from: https://doi.org/10.1007/s12 528-019-09230-1 (2019).

[28] Oh, E. G., Chang, Y., \& Park, S. W. Design review of MOOCs: application of e-learning design principles. Journal of Computing in Higher Education, (0123456789). Retrieved from: https://doi.org/10.1007/s12528-019-09243w (2019).

[29] ONU. Educación de calidad: por qué es importante. Un.Org, 1-6. Retrieved from http://www.un.org/\%0Ahttp://www.un .org/sustainabledevelopment/es/wp-content/uploads/sites/3/ 2016/10/4_Spanish_Why_it_Matters.pdf (2017). 
[30] Ovbiagbonhia, A. R., Kollöffel, B., \&Brok, P. den. Educating for innovation: students' perceptions of the learning environment and of their own innovation competence. Learning Environments Research, 22(3), 387-407. Retrieved from: https://doi.org/10.1007/s10984-0 19-09280-3 (2019).

[31] Perales Franco, C., \& McCowan, T. Rewiring higher education for the Sustainable Development Goals: the case of the Intercultural University of Veracruz, Mexico. Higher Education. Retrieved from: https://doi.org/10.1007/s10734020-00525-2 (2020).

[32] Pérez, L., Jordano, M., \& Martin-Cuadrado, A. M. Los NOOC para la formación en competencias digitales del docente universitario. Una experiencia piloto de la Universidad Nacional de Educación a distancia ( UNED ). NOOCs for the development of university teachers' digital competences . A pilot experien. RED. Revista de Educación a Distancia, 55, 1-35. Retrieved from: https://doi.org/http:// dx.doi.org/10.6018/red/55/1(2017).

[33] Ross, S. M. Technology infusion in K-12 classrooms: a retrospective look at three decades of challenges and advancements in research and practice. Educational Technology Research and Development. Retrieved from: https://doi.org/10.1007/s11423-020-09756-7 (2020).

[34] Roura-Redondo, M.,y Osuna-Acedo, S. Aprender con el diálogo, dialogar para aprender: Estudio de caso en MOOC. Index Comunicación, 8(2), 103-128. (2018).

[35] Sánchez Hernández, María Enriqueta \& Andrade Palos, Patricia. Análisis factorial confirmatorio de la Escala de Involucramiento Escolar para Adolescentes (EIE-A).
RevistaActualidadesInvestigativasenEducación, 20(1), 1-18. Doi. 10.15517/aie.v20i1.40020 (2020).

[36] Saravia, J. C., Analisis de varianza (ANOVA). Stats Sos Retrieved from: https://statssos.net/2015/02/27/analisisde-varianza-anova-alegria-o-terror/ (2015).

[37] Siemens, G., \& Leal, E. D. Conectivismo: una teoria de aprendizaje para la era digital, 10. Retrieved from: https://s3.amazonaws.com/academia.edu.documents/38778 149/13_conectivismo_era_digital.pdf?AWSAccessKeyId= AKIAIWOWYYGZ2Y53UL3A\&Expires $=1549576205 \& \mathrm{Si}$ gnature $=\mathrm{E} 0 \times \mathrm{TaLrGSAXyOZi0cCe} \% 2 \mathrm{Bk} \% 2 \mathrm{FgqlSQ} \% 3 \mathrm{D} \&$ response-content-disposition $=$ inline $\% 3 \mathrm{~B}$ filename\%3DEste_trabajo_est (2013).

[38] Terrazas, R., \& Murillo, R. S. La educación y la sociedad del conocimiento Education and the knowledge society. Perspectivas, 32, 145-168. Retrieved from:https://www.red alyc.org/pdf/4259/425941262005.pdf (2016).

[39] Vate-U-Lan, P. Psychological impact of e-learning on social network sites: online students' attitudes and their satisfaction with life. Journal of Computing in Higher Education, 32(1), 27-40. Retrieved from: https://doi.org/10.1007/s12528-019 -09222-1 (2020).

[40] Yoonil, A., \&Heejung, S. Uses of social network topology and network-integrated multimedia for designing a large-scale open learning system: case studies of unsupervised featured learning platform Design in South Korea. Multimedia Tools and Applications, 78(5), 5445-5462. Retrieved from: https://doi.org/10.1007/s11042 -018-6658-1 (2019). 